\title{
Indonesia Defense Diplomacy in Enhancing Indonesia-China Defense Cooperation
}

\author{
Surryanto D. Waluyo, Helda Risman*
}

\author{
Faculty of Defense Strategy, Indonesia Defence University, J1. Sentul - Citeureup, Sentul, Kec. Citeureup, Bogor, Jawa Barat 16810, Indonesia
}

DOI: $10.36347 /$ sjahss.2020.v08i12.004

| Received: 02.12.2020 | Accepted: 15.12.2020 | Published: 30.12.2020

*Corresponding author: Helda Risman

Abstract

Global politics has transformed its polarity and distribution of power in the past two decades. The significant increase in China's military and economic capabilities displaced the United States from a prominent actor in international relations, especially in the Asia Pacific region. Countries view that initiating and strengthening cooperation in various fields with China promises hope for its national development amidst the strategic challenges of today's contemporary era. Indonesia, a new middle power that continues to grow, is trying to shift the negative sentiment of China in the New Order era by exploring comprehensive partnerships that have proven successful in the fields of economy and connectivity. The expansion of cooperation to the defense sector is then initiated and implemented in order to follow up on transnational issues that have the potential to disrupt the intensive cooperative relationship that is already taking place between the two parties. This study analyzes the realization of Indonesia's defense diplomacy, which is carried out to increase Indonesia-China defense cooperation. In the framework of qualitative methods, researchers contest the current reality of Indonesia-China defense cooperation with the concept of national interests, the concept of security dilemmas, and the theory of defense diplomacy. This research then finds that Indonesia has not received valuable benefits from defense cooperation with China to fulfill Indonesia's national interests in terms of maintaining sovereignty and territorial integrity.

Keywords: China, comprehensive partnership, defense diplomacy, defense cooperation, national interest.

Copyright $(\mathcal{C} 2020$ The Author(s): This is an open-access article distributed under the terms of the Creative Commons Attribution 4.0 International License (CC BY-NC 4.0) which permits unrestricted use, distribution, and reproduction in any medium for non-commercial use provided the original author and source are credited.

\section{INTRODUCTION}

Indonesia and China are two countries with promising economic development in Asia. The broad common interests in various development fields lead to both the implementation and the prospect of a closer strategic partnership. The ongoing strengthening of bilateral relations in infrastructure, agriculture, finance, and other sectors can be projected towards defense and security cooperation.

The Indonesia-China consensus in 2007 paved the way for the realization of a comprehensive defense partnership between the two. Indonesia and China agree to exchange information on defense issues and institutions, professional education and training, mutual visits and joint research, exchange of scientific and technological data, exchange of technicians and trainers, cooperation in the defense industry, and other cooperation in the defense sector. Both of them realize that following up on strategic issues in the region together is crucial both for securing their respective national interests and for the continuity of their ongoing multi-aspect partnership.

The fluctuating relations with China since Indonesia's independence returned to stability and warmed up when President Susilo Bambang Yudhoyono (SBY) and $\mathrm{Xi}$ Jinping agreed to sign a Comprehensive Strategic Partnership (CSP). China tried to eradicate its negative image due to the G30-S PKI incident [1] through symbolic gestures that emphasized its desire to be friendly "friends." The confidencebuilding between Indonesia and China still faces the challenge of China's assertive behavior in the South China Sea, which disrupts Indonesia's sovereign rights over its Exclusive Economic Zone [2].

Military cooperation has been established in operations, training, logistics, and cooperation at the force level and at the TNI Headquarters level. Several forums were held, and military officials' visits were organized in the context of realizing the above CSP. The problem arises because the military partnership has not been deepened due to the absence of a fundamental 
foundation for cooperation such as a mechanism for military student exchange and a mechanism for implementing the bilateral joint exercise "Sharp Knife" since 2011. The same situation applies in the realm of maritime cooperation. Not to mention, Indonesia's status as an ASEAN member appears to limit the intensity of further cooperation with China.

President Joko Widodo reaffirmed the strategic partnership commitment above through his diplomatic visit to China on 26-28 March 2015, which resulted in a joint statement. In defense and security, among others, it was agreed to take advantage of the Bilateral Polhukam Dialogue to increase cooperation to combat transnational crime, anti-drug trafficking, anticorruption, extradition, and cybersecurity. The two sides are committed to intensifying high-level military exchanges through the defense and security consultations, joint commissions on defense technology and industry, and naval dialogue. Furthermore, the two agreed to deepen cooperation in joint training, training, military industry, military equipment trade, reciprocal visits from military ships, personnel training, and multilateral security [2].

China has outlined its defense cooperation with other countries to accommodate the achievement of its national goal, China's Dream 2049. Since being elected president in 2013, Xi Jinping has aggressively popularized this slogan with the core of making China a prosperous and prosperous socialist country by 2049 [3]. Many national interests are derived from this vision, including maintaining sovereignty and territorial integrity, maintaining internal stability and political rules, maintaining economic growth, and securing China's status as a great power [4].

From the explanation above, we realize that there are ups and downs in the Indonesia-China relationship. Even in the era of advancing bilateral relations between the two of them, there are still many obstacles in operationalizing the comprehensive partnership agreed upon at the strategic level. However, Indonesia continues to consistently strive to increase defense cooperation in order to accommodate its national interests as well [5]. The formulation of this problem is outlined in two research questions that will be answered in the discussion section: (1) How is defense cooperation between Indonesia and China viewed from the concept of national interests? and (2) How is Indonesia's defense diplomacy in enhancing defense cooperation between Indonesia and China?

\section{MATERIAL/METHODS}

This study uses a qualitative method with a descriptive-narrative approach, in which data sources consist of primary and secondary sources, which will be obtained in the form of narrative data and descriptions of primary data. Data collection in this study using three techniques: observation, interviews, and documentation study. Interviews were aimed at the Center for Chinese Studies in Jakarta, the Coordinating Ministry for Political, Legal, and Security Affairs, the Ministry of Defense observers, and Chinese issues practitioners. Secondary sources are taken from journal articles, magazines, internet sites, and related official documents. The data analysis technique uses an interactive model consisting of data condensation, data presentation, and concluding [6].

\section{Concept of National Security}

The national interest is conceptually used to explain the behavior of a country's foreign policy. Hans J. Morgenthau, Frederick L. Schumann, George F. Kennan, and Henry A. Kissinger popularized the premise that every diplomatic activity refers to the national interest. This view is a critique of the idealist school that puts forward moral, legality, and ideological factors in the foreign policy strategy [7].

Hans J. Morgenthau argued that the essence of the national interest is survival. Every nation's essential ability is to protect their physical, political, and cultural identity from other countries' interference. This conception departs from Morgenthau's assumption that the international system is not a system full of harmony and a system that is always destined to cause war. It is further assumed that there are only conflicts and the threat of war at certain levels, and all of these can be reduced by gradually adjusting them to conflicting interests through diplomatic measures [8].

The national interest will be used as a reference in the formulation and determination of a grand strategy or national security strategy. A stable national security is a precondition for the smooth implementation of national development to achieve national goals. Within this framework, national security is a dynamic national interest. National security is influenced by the dynamics of changes in the strategic environment as well as factors from within the country, including economic development, education, community welfare, political dynamics, and interactions between communities [9].

\section{Theory of Security Dilemma}

The security dilemma describes the situation that occurs to analyze the international system from a neorealist perspective. This situation affects the dynamics of interaction between countries, making the state increase its security to reduce other countries' security level. Uncertainty or uncertainty is a character of an anarchic system [10].

An anarchic system with uncertainty over security encourages a country to create its defense system to counterbalance the hegemon's power. The anarchic international system encourages countries to continue to carry out power maximizing behavior. The 
cause of increasing power is because no authority guarantees state security in an anarchic system [11]. In essence, the security dilemma concept explains that the anarchy system encourages every country to improve its country's security. This increase is referred to as self-help efforts, but these actions impact the insecurity of other countries so that the resulting reaction is to compete with each other to improve each other's security. This is due to the fear aspect arising from the uncertainty of its own security and is strengthened by an increase in strength to secure oneself from threats.

\section{Theory of Defence Diplomacy}

Defense diplomacy is a concept that describes the use of armed forces and related infrastructure such as the ministry of defense in peacetime as a foreign and defense policy tool. Defense diplomacy is cooperative, which is different from these institutions' primary function, namely the use of force and threats. Defense diplomacy is intended to build cooperative relations with other countries and support other countries in reestablishing their armed forces [12].

Several aspects shape the current definition of defense diplomacy. First, defense diplomacy is a cooperative activity carried out by the military and related institutions during peacetime. Second, defense diplomacy includes cooperation that includes the military's traditional functions, namely, efforts to balance rival countries and new military tasks outside its traditional duties. Third, unlike the past, defense diplomacy now involves not only military cooperation with friendly countries but also with countries that have the potential to become enemies.

The Indonesian defense white paper explains that defense diplomacy is an instrument in realizing national interests in the defense sector, one of which is to increase soldiers' professionalism through the field of education, training, and cooperation in the defense industry. This proves that defense diplomacy's capacitybuilding function is intended to increase national resilience from threats [9]. Defense diplomacy has several objectives, namely presence or representation, deterrence, negotiation, and bargaining position, increasing capability, increasing credibility, reducing the desire of countries with different interests to do unwanted things, intelligence, increasing contacts, building public opinion, promoting international law, building mutual trust, and regional expansion [13].

Defense diplomacy activities vary widely and span various fields: including bilateral and multilateral contacts between military and civilian officials, the appointment of defense attaches or advisors, following up on defense cooperation agreements, training of defense and civilian personnel, deploying training teams and other experts, providing expertise and advice on matters related to defense, conducting ship visits and other military-related exchanges, conducting training, and providing military equipment and technical expertise [12].

From the explanation above, the researcher draws a synthesis that defense diplomacy is a kind of diplomacy carried out by the military or the Ministry of Defense. This activity is carried out in peacetime to resolve conflicts, avoid conflicts, and increase the defense capability of a country. Of course, the function of defense diplomacy, both at the bilateral and multilateral level to prevent conflict, is inseparable from the government's political and foreign policy objectives.

\section{Theory of Defence Cooperation}

In the international system, each country requires interaction with other countries. This then demands cooperation to fulfill national interests [14]. International cooperation refers to policy coordination behavior in specific problem areas based on basic agreements or partial agreements between international actors based on shared interests [15]. International cooperation generally takes place in a decentralized nature that lacks effective institutions and norms for units that are culturally different and geographically separated. Thus, the need to address problems involving insufficient information about each party's motivations and goals is critical [16].

China has an approach to international cooperation. Xi Jinping has proposed building a new type of international relations that promotes win-win cooperation. This concept is reflected in the field of political economy, cultural security, and all other aspects of China's cooperation with countries worldwide [17].

This win-win concept underlies the formation of partnerships that treat each other equally and understand each other, advocate for adherence to multilateralism and not unilateralism, discard the old premise that when one party wins, the other will lose, accommodate dispute resolution through dialogue, negotiate differences with diplomacy, encouraging to abandon all legacies of cold war era thinking and build new concepts that are common, comprehensive, cooperative, sustainable, and jointly address traditional and non-traditional security threats.

One of the fields of international cooperation is defense cooperation. Defense cooperation is a form of cooperation that emphasizes the national interest of a country. This cooperation is sensitive because it concerns the sovereignty of the state, security, stability, and the welfare of the people [13]. In the Indonesian Defense White Paper, it is stated that the purpose of defense cooperation is to build mutual trust between countries, respect one another's sovereignty, build mutually beneficial relationships, and also as a tool to prevent conflicts between countries. Another goal is to 
increase the capability and professionalism of TNI soldiers through cooperation in the field of education, training, and cooperation in the defense industry. To achieve the maximum results from defense cooperation, qualified defense diplomacy is needed [9].

\section{RESULTS \& DISCUSSION \\ Indonesia's National Interests}

Indonesia's national interest is to maintain the existence based on Pancasila and the 1945 Constitution as well as ensuring the smooth running of national development to realize national goals. The national interest is manifested by observing three main principles. First, the life order of the people of the nation and state of Indonesia is based on Pancasila and the 1945 Constitution. Second, sustainable national development with an environmental perspective and national resilience is based on the archipelago's insight. Third, to utilize national potential and strength facilities in a comprehensive and integrated manner [9]. As mandated on the constitution, Indonesia interests are protecting the entire Indonesian nation, promote the general welfare, educate the nation's life, and participate in building a world order based on the freedom of eternal peace and social justice. Related to the achievement of this national interest, according to Julan in personal communications:

National interest cannot be advanced without cooperating with other countries, but in order to obtain benefits for the interests of the state and nation, this cooperation also needs to pay attention to equality, we (Indonesia) must be in an equal position with China or with any country we cooperate with. Indonesia must sit in line with countries that collaborate, accept, or get the same results from the cooperation carried out. To achieve the equality, it is necessary to have a strategy of a tug-of-war of interests in the cooperation carried out so that it will put Indonesia in an equal position with China.

Chinese leaders have developed China's strategy to arouse Chinese nationalism to fulfill its national interests. This strategy has succeeded in arousing a sense of Chinese nationalism throughout the world via the active role of the Chinese diaspora, found in most parts of the world. In fact, Indonesia can take advantage of this diaspora in cooperation with China. Indonesia can take advantage of the Chinese diaspora born and live in Indonesia but have blood ties to China. What China has done in arousing the spirit of Chinese nationalism around the world to achieve its national interests can also be done by Indonesia towards Indonesia's national interests by utilizing the potential of the Indonesian people in the homeland and the Indonesian diaspora, which are spread throughout the world including in China as well.

\section{China's National Interests}

Starting in the 1980s, then China's leader, Deng Xiaoping, emphasized in several key speeches that economic growth and modernization are the main tasks of the Chinese Communist Party and the government. Under Deng Xiaoping's instructions, China's foreign policy was successfully reversed into making diplomacy and national defense serve domestic economic growth. In the 1990s, when facing economic sanctions and the "Chinese threat theory", Deng Xiaoping proposed the basic principles of China's foreign strategy, namely: "stay humble and do something (蹈光养晦 有所作为 / taoguang yanghui yousuo zuowei).

China's threat theory made the government realize that accumulating material capabilities would trigger widespread anxiety. It is also realized that the inherent ideological conflict between China and democratic countries can increase tensions. To make other countries accept the rise of China led by the Chinese Communist Party, the Chinese government seeks to engage in a liberal order dominated by the United States by actively participating in various international institutions and organizations. It indicates that China will act as a rule follower rather than a rule breaker [4].

President XI Jinping formulated that China's current goal is more than just the accumulation of material capabilities. Therefore, the principle of "stay humble and do something" has been changed to "strive for achievement" (奋发 有为 / fenfa youwei). China wants today to become a widely recognized and respected great power with far-reaching prestige and influence to maintain its great power status. China has begun to take a firm stance by defining its control over the many areas of national interest. Besides covering traditional significance areas such as Tibet, Xinjiang, and Taiwan, China also affirms its national interest in several disputed areas such as the South China Sea and the East China Sea [4].

China's choice of strategic national interest is based on two factors. First, China's rise is taking place in a unipolar system dominated by the United States, which means China will inevitably face obstacles from the world's most powerful country. Other major powers in the Asia Pacific region, such as India and Japan, can cooperate with the United States in stemming China's strategic rise. Second, with increasing sea and land power, China has to deal with many neighboring countries. Therefore, maintaining relations with major powers and surrounding countries simultaneously is equally vital in China's foreign policy [4].

Thus, it can be formulated that China's first national interest is a defensive national interest related to the state's ability and willingness to defend its 
domestic demands such as political stability, development, and economic growth. This interest is only defended, not expanded. Second, constructive national interests, namely the state's efforts to achieve convincing results by expanding its national interests to further relate to other countries' interests. The three core interests of the enemy, which show that China is starting to apply a two-way approach in its foreign policy, which is to have a growing willingness to use a decisive strategy to counter the suppression pressure exerted by the existing hegemon but still use reassurance strategies to other big, medium, or small powers. Regarding the role of the diaspora in achieving China's national interests, a Chinese historian, Tuti, in personal communication:

The existence of strong clan ties and cultural linkages between the diaspora and ancestral lands and the encouragement of devotional beliefs according to confusional teachings 孝 (Xiao / filial piety) makes this strong sense of nationalism grow by itself as a symbol of showing devotion to China's ancestral land and a strength for China in building its relationship with the world community, and this is China's strong asset that no other nation in the world has in fulfilling its national interests.

\section{Indonesian Defence Diplomacy: Indonesia-China Defence Cooperation}

During the last decade, Indonesia has confronted the reality of the intensification of the USled Indo-Pacific strategy. Indonesia responded to this situation by initiating collective guidance on conducting international relations in the Southeast Asia region, which was later launched as the ASEAN Outlook on the Indo-Pacific in 2019. This move is claimed to be a manifestation of the consistency of Indonesia's free and active politics, which is apprehended by being neutral towards US-China rivalries and diverting it by mobilizing a commitment to enhancing cooperations facilitated by an intra-regional organization [18]. Furthermore, in addressing the Indo-Pacific issue and the dynamics of the region as a whole, Indonesia has another option to pick a bilateral approach by strengthening defense cooperation with China.

The signing of the strategic partnership framework by Indonesia and China in 2005 became the starting point for defense cooperation between the two countries. Defense cooperation was re-launched by Indonesia and China in 2007 within the framework of the Bilateral Consultation Forum for the IndonesianChinese Defense Sector as part of the Strategic Partnership agreed by the two countries' leaders on 25 April 2005. Based on the agreement, defense cooperation between Indonesia and China is growing or gradually increasing from visiting high-ranking military and defense ministries of the two countries to joint training between the Indonesian National Army (TNI) and the Chinese People's Liberation Army. Defense cooperation between the two countries is a strategic defense relationship and is always expected to strengthen bilateral relations between the two countries that have been established in various fields [19].

In the last decade, China has remained ambitious to develop defense cooperation to protect China's national interests. Defense cooperation between Indonesia and China has increased significantly from year to year, which has shown a strategic relationship that can benefit both parties. Regarding the principle of benefiting both parties, the Chairman of the China Study Forum in Jakarta, Rene, in personal communication, commented on China's new theory of "win-win" international relations as follows:

We must be able to translate this win-win according to our view of the Indonesian people that if China gets five, then Indonesia must be able to get five as part of the cooperation agreement. So far, the equality of fate with all nations in the world as China's rhetoric promotes equality and fate is different in reality. For example, in the Covid-19 Pandemic, most people have not yet dared to hold a gathering for a celebration, but people in China have dared to do so in an autumn celebration ago. It shows no equality of fate and equality between Chinese society and the world community in general. Things like this need to be alert to us in cooperating with China regarding the win-win theory.

Several forms of defense cooperation undertaken between Indonesia and China include cooperation in exchanging information on defense institutions and issues, cooperative exchange of officials in the context of joint training and research, official visits, and defense dialogue forums. Official exchange cooperation in the context of education, training, and joint research according to sources (personal communication, 2020):

Cooperation in the field of education between China and Indonesia is carried out by sending officers to each other to attend the commando school (Sesko) of the force and Lemhanas as well as cooperation through the exchange of Military Academy Cadets. China can send Mandarin native speakers to Indonesia to teach Military Academy Cadets and Defense University students as well as provide guidance and training for Mandarin teachers at the Kemhan language training center. In the era of the $1990 \mathrm{~s}$, to be precise after the normalization of relations between Indonesia and China until the beginning of 2000, the mandarin language teachers of the Kemhan Language Education and Training Center, in turn, took advanced Mandarin education at the Chinese PLA Chinese Language Center, so that all the Kemhan language education and training center teachers had received Mandarin education at PRC. This is part of the implementation of Indonesia's China defense cooperation. 
This kind of cooperation should be maintained and further enhanced for the sake of Indonesian interest. In terms of personnel amount in the educational exchange between Indonesia and China, more Indonesian officers attend education in the PRC than Chinese officers who attend education in Indonesia Sesko TNI (Indonesian Armed Forces School of Staff and Command), Sesko Angkatan (Indonesian Army/Navy/Airforce School of Staff and Command) or Lemhanas (National Resilience Institute). Indonesian Armed Forces have sent a total of 203 personnel. Meanwhile, China has only sent 16 personnel. Cooperation in the education sector benefits Indonesia more than China.

Indonesia gains more benefits than China in the following aspect, but Indonesia should not in complacency yet. The government encouraged to expand the range of advantages that can be extracted from any diplomacy, particularly defence diplomacy. For example, in the case of the South China Sea, a successfulness can be measured by forcing China to recognize the internationally recognized-EEZ over its claim of traditional fishing ground.

Several mutual visits between defense officials have been held as another manifestation of defense diplomacy between Indonesia and China. On 16 December 2013, the Minister of Defense of China, Chang, paid a visit to Indonesia, especially to the Ministry of Defense. China feels it must develop national airspace sovereignty. In this case, the enforcement of ADIZ (Air Defense Identification Zone) will not interfere and change the legal nature and legal position of the territorial airspace. Apart from that, China would also like to discuss in more depth the offer of assistance to monitor the Sunda Strait, which was previously raised during the Minister of Defense's visit to China in 2012.

On 26-28 March 2015, President Joko Widodo's state visit to China resulted in a Joint Statement on defense and security. One of the statement's contents is to agree on a bilateral dialogue on politics, law, and security, with topics that include discussions on increasing cooperation to combat transnational crime, trafficking, anti-drugs, anticorruption, extradition, and cybersecurity. Both parties agree that terrorism is the common enemy of humanity, so it is necessary to strengthen cooperation in intelligence exchange, joint investigations, against cyber terrorists and eradicating extremism and addressing the threat of international terrorism together. Indonesia and China are committed to further strengthening high-level military exchanges through the defense and security consultations, joint commissions on defense technology and industry, and dialogue between forces. They also agree to increase the level of cooperation in joint exercise and training, military industry and trade, reciprocal visits from military ships, personnel training, and multilateral security.

Various official visits have been carried out both as a continuation of previous official visits and as an implementation of a strategic partnership and a joint statement signed by the heads of the two countries. From 15 to 19 December 2019, the Indonesian Minister of Defense visited Beijing in a Courtesy Call with the Chinese Defense Minister. The results of the meeting is the Chinese Minister of Defense plans to provide a grant for Chinese language laboratory equipment to the Ministry of Defense as a form of concern for the Chinese government in increasing cooperation in the education sector.

Apart from official visits and military cooperation in the form of personnel exchanges for education, cooperation has also been carried out at the force level in various fields, such as the Navy to Navy Cooperation Talks between the Chinese People's Liberation Army Navy and the Indonesian Navy. In operational and training cooperation between TNI troops and the PLA, joint exercises have been carried out since 2011. The last joint exercise called "Sharp Knife Airborne" was held between Korpaskhas in 2014, Sharp Knife in 2015 between Amphibious Reconnaissance TNI AL and the Navy-China.

In terms of cooperating with China, to benefit and fulfill Indonesia's interests, cooperation is carried out proportionally and professionally by looking at Indonesia's capabilities in working together. Indonesia must be selective in choosing fields of cooperation, such as technology transfer in the defense industry, which must have clear technological stages according to the needs of defense equipment. Thus, defense cooperation with China will still provide benefits for Indonesia. In terms of diplomacy carried out by China in collaborating with other countries, Xue Shong (CCRNC Fudan University, at the LIPI $\mathrm{P}$ to $\mathrm{P}$ Indonesia-China Connection: Challenges and Strategy Seminar, 2020) said that:

The Chinese government has included the principle of tolerance in conducting diplomacy. So that China no longer wants to use ancient Chinese rhetoric like the old dynastic era, which was only useful for Chinese interests. The statement that the people of Indonesia and China do not have the same fate is unreasonable. As said in this language, our people can celebrate the "Chinese Big Day" while Indonesia is still struggling to face the Covid-19 pandemic and various BRI criticisms, which has benefited China a lot. China has responded to this by making many policy changes such as fulfilling Indonesia's interests so that BRI can develop small islands in Indonesia through BRI's interconnectivity. 
The strategic partnership between Indonesia and China is beneficial in strengthening defense cooperation between the two countries. This cooperation includes military trade cooperation, personnel training, joint exercises, and defense technology transfer. The reasons and conditions for defense cooperation between the two countries are sufficient because of the complicated geopolitical security situation in which the two countries are located. Second, the development of sustainable economic cooperation between the two parties requires a safe environment.

Cooperation between the two countries is in line with a new, win-win international relationship, but certain mutual trust problems require concerted efforts from both sides to resolve them. Also, the cooperation mechanism level is still low and is more of a cooperation mechanism for informal security. How to achieve change from crisis response is also an issue that current security cooperation mechanisms must resolve [15].

China's claim to the South China Sea will be an obstacle to the defense cooperation between Indonesia and China because it shows China's rejection of the 1982 UNCLOS as an international legal effort that has been ratified by Indonesia. Promoting an intense dialogue forum involving the South China Sea stakeholders will further dampen China's desire for China's national interest in the South China Sea. Increasing cooperation in the form of joint patrols between Indonesia and China in the South China Sea area is likely to soften China's attitude towards its interests in the South China Sea and strengthen China's defense cooperation relations with Indonesia.

In Indonesia-China cooperation, defense diplomacy is also used as an instrument to enhance ideal defense relations. This defense relationship is not limited to overcoming non-military threats to the two countries but is also useful for increasing confidence building to maintain the principle of peaceful coexistence. Indonesia and China have held defense dialogue forums both at the Ministry of Defense of each country and at the level of the force, exchange of defense and institutional information, and joint operations and exercises. It is proving mutual trust strategically and an instrument to increase the two countries' military capabilities.

\section{CONCLUSION}

Defence cooperation with China has not resulted in advancing Indonesian national interest in terms of maintaning its territorial integrity. Chinese fishing boats, escorted by its coast guards, keep rushing to Natuna water. The future of Indonesian defense cooperation should be able to help protecting the entire nation and increasing welfare, especially in areas bordering neighboring countries and Chinese waters.
Indonesia's defense diplomacy in enhancing IndonesiaChina defense cooperation pragmatically seeks to maintain the current conditions of bilateral relations between Indonesia and China in the region. In contrast, there has been no substantial effort to change the existing conditions of defense cooperation in a transformative manner so that it looks monotonous and normative. Defense diplomacy that is carried out needs to uphold the reciprocal principles of cooperation, equality, and translate a win-win solution as a cooperative position between Indonesia and China. So far, the cooperation that has been built, such as building interconnectivity in the BRI project, has only benefited China's national interests but has not added value to Indonesia's national interests in maintaining Indonesia's territorial integrity, safeguarding the sovereignty, and protecting the entire Indonesian nation.

\section{REFERENCES}

1. Muas TE. Restoring Trusts without Losing Face: An Episode in the History of China - Indonesia Relationship. Tawarikh. 2015;6(2).

2. Priyandita G. From Rivals to Partners: Constructing the Sino-Indonesian Strategic Partnership. Global: Jurnal Politik Internasional [Internet]. 2019 Jul 5;21(1). Available from: http://global.ir.fisip.ui.ac.id/index.php/global/articl e/view/361

3. Miller T. China's Asian Dream: Empire Building along the New Silk Road. Zed Books; 2017.

4. Ye X. Rediscovering the Transition in China's National Interest: A Neoclassical Realist Approach. Journal of Current Chinese Affairs [Internet]. 2019 Apr 11;48(1):76-105. Available from:

http://journals.sagepub.com/doi/10.1177/1868102 619876830

5. Kementerian Pertahanan. Buku Strategi Pertahanan Negara 2015. Jakarta; 2015.

6. Miles M, Huberman M, Saldaña J. Qualitative Data Analysis: A Methods Sourcebook. 3rd ed. Los Angeles: SAGE; 2014.

7. Couloumbis $\mathrm{T}$, Wolfe J. Introduction to international relations power and justice. New Jersey: Prentice Hall; 1981.

8. Sitepu A. Studi Hubungan Internasional. Yogyakarta: Graha Ilmu; 2011.

9. Kementerian Pertahanan. Buku Putih Pertahanan. Jakarta; 2015.

10. Jervis R. Cooperation under the Security Dilemma. World Politics [Internet]. 1978 Jan 13;30(2):167-214. Available from: https://www.cambridge.org/core/product/identifier /S0043887100016191/type/journal_article

11. Mearsheimer JJ. The tragedy of great power politics. New York: W. W. Norton \& Company; 2001.

12. Cottey A, Forster A. Reshaping Defence Diplomacy: New Roles for Military Cooperation and Assistance. London: The International 
Institute for Strategic Studies; 2004.

13. Supriyatno M. Tentang Ilmu Pertahanan. Jakarta: Yayasan Obor Indonesia; 2014.

14. Toma PA, Gorman RF. International Relations: Understanding Global Issues. Brooks/Cole Publishing Company; 1991.

15. Tao LW, Thamrin S, Waluyo S. Kerjasama Keamanan China - Indonesia Guna Menangkal Ancaman Keamanan Maritim Kedua Negara. Jurnal Strategi Pertahanan Laut. 2019;5(3).

16. James E. Dougherty RLP. Contending Theories of International Relations: A Comprehensive Survey. 4th ed. Longman; 1997.

17. Jiechi Y. A New Type of International Relations. Horizons: Journal of International Relations and Sustainable Development [Internet]. 2015 Dec 1;(4):12-9. Available from: https://www.jstor.org/stable/48573553

18. Oktaviano D, Mahroza J, Risman H. Indonesia Defense Strategy Towards Indo-Pacific ( Case Study: The ASEAN Outlook on the Indo-Pacific ). International Affairs and Global Strategy [Internet]. 2020 Feb 29;80:21-9. Available from: https://iiste.org/Journals/index.php/IAGS/article/vi ew/51417

19. Qingsong Z. Pengaruh "The Belt and Road Initiative" (BRI) Terhadap Implementasi "Kebijakan Poros Maritim Dunia" (PMD) Guna Meningkatkan Kerjasama Strategis ChinaIndonesia. Pertahanan [Internet]. 2018; Available from:

http://jurnal.idu.ac.id/files/journals/16/articles/434 /attachment/434-1924-1-AT.doc. 